\title{
Analysis on application of different grape varieties in the production of icewine. A review
}

\section{Viktoria Ostapenko}

\author{
Odesa National Academy of Food Technologies, Odesa, Ukraine
}

\section{Keywords:}

Icewine

Ice wine

Grapes

Late maturing

Climate

\section{Article history:}

Received 12.10.2016

Received in revised form 20.12.2016

Accepted 27.12.2016

\section{Corresponding author:}

Viktoria Ostapenko

E-mail:

viktoriya_velass@mail.ru

DOI: $10.24263 / 2304-$

974X-2016-5-4-7

\section{Abstract}

Introduction. The choice of suitable vine cultivars to icewine production is exerting an increasingly influence on market supply expanding the premium segment of agricultural sector.

Materials and methods. Databases and international laws in winemaking were used to assessing the completed performance associated with application of different grape varieties for icewine production in different countries.

Results and Discussion. Current study illustrates the comprehensive range of grapes used by winemakers who decided to leave vines during low temperature in different producing countries among which are Germany, The Czech Republic, Austria, Slovenia and Canada. The states listed compose the most diverse grape groups for finished wines. Europe has the various grapes growing in winter to freeze but the total Icewine amount is lower compare to countries located in the North America including Canada and the United States of America.

Majority of countries largely adopt Vitis vinifera possessing thick-skin that offers better protection against winter damage, however, varieties of this class are relatively sensitive to weather than hybrids or autochthonous grapes. Riesling is the most common used for icewine processing due to appreciation of characteristics of vine during winter period.

Climate conditions are the main contributor to obtaining Icewine crops that can significantly decrease the expected volumes of harvest, thuswise grapes protective measures are provided before low temperatures.

Conclusions. The result obtained from review based on the determining of the use of various cultivars demonstrates the development and expansion of icewines within the world wine society. 


\section{Introduction}

Harvest dates need to be considered carefully since they are based on subjective evaluations of optimum fruit composition in view of ulterior wine quality, whose definition is exposed to individual interpretation and trends, and may also depend on commercial targets, market constraints, processing capacity and other factors [1]. According to VQA in Canada grapes for Icewine ${ }^{1}$ production must be harvested no earlier than November, picked while the air temperature is $-8^{\circ} \mathrm{C}$ or lower and the optimal time for harvesting is $-7^{\circ} \mathrm{C}$ in European countries [2]. The grapes must be harvested and pressed at these same temperatures. The grapes are harvested at $\leq-8{ }^{\circ} \mathrm{C}$ and pressed at low temperature to obtain the minimum juice $35^{\circ}$ Brix required for icewine in Canada. During pressing, much of the water is retained with the grape skins as ice, while a juice is highly concentrated in sugars, acids and aroma compounds [3].

The choice of cultivar for icewine production is important as it can affect the sensory and chemical composition of the obtained wine. Generally, grape quality is the key characteristic for the production of quality wines. The total requirements for grapes used in icewine production are a resistance to rot and other diseases, the healthier structure, technological maturity and the chemical composition of grapes. Characteristics of a good variety for icewine production are that it has thick skin, be late maturing, possess a high natural acidity and be resistant to low winter temperatures, but should be noted yield of grape juice per tone of grapes is low [4]. According to Definition of the vitivinicultural products by code sheet of OIV [5] all grapes used for Icewine production should come from the same region.

Recently many countries have used comprehensive number of varieties and styles for icewine production, yet to be characterized in the literature [23, 30-33, 43, 44]. The choice of variety plays one of the important roles in the production of icewine. A number studies are focused on searching of solutions for stability of grapevines during low winter temperatures in order to obtain the good harvest.

The objectives of this research were:

1. To determine the main cultivars using for Icewine production across the world;

2. To indicate the substantial reasons for selection of grapes appropriated to naturally freezing. Redistribution in wine production may occur within continents, moving from declining traditional wine-growing regions to novel suitable areas [6]. Thereby the interest about new types of wines and new cultivars has increased.

\section{Materials and methods}

Information about Icewine grapes was obtained from bibliographic sources including articles, researches [1-4, 8-11] and thesis [7, 52] from Canada and then summarized using statistic data [18-20] and wine reports [22-26, 41-43] from different countries. As the

${ }^{1}$ Icewine (title of wine bottle) is predominantly used by Americans. Canadian researchers in the articles mark premium wine as Icewine, always with capital letter. Most of producers determine sweet wines respectively to official languages, but according to acts belonged to OIV producers should indicate wines like Canadians make. Author of this article uses the name of wine in accordance with the marking of a particular country. 
principal indicator climate influence on the production of icewine was studied [12-17]. Company's presentations [21, 44-46] were foundation for determination of used grape varieties for icewine production. In order to show possible grape cultivars appreciated for icewine production various vines possessing cold-resistant and disease-resistant originated from different wine areas were examined [27-29, 34-39]. The official sites of wine governments were the main basis to choosing enterprises having special dessert bottles in their shops. Statuses and official documents of International Organisation of Vine and Wine [5] and annual reports of The Vintners Quality Alliance [31,56] were indicators for determination peculiarities of utilized grapes. Data for the climatic conditions of wine regions could explain the layout of icewine producers. Figures presented in current review were produced using Excel software (MS Office 2007, Microsoft Corporation, Seattle, WA).

\section{Results and Discussion}

\section{Grape parameters for Icewine production}

Icewine is the only wine type for which the soluble solids concentration at grapes maturity is irrelevant, because the harvest of grapes for its production is performed at temperature that is critical and leads to freezing of the water inside the berry and concentrating all its components [7].

The resistance of low winter temperatures, high natural acidity, late ripening, tough skins and stems and reasonable resistance to diseases have been identified as the most important characteristics of grape varieties used for Icewine production, and largely explains the predominance of Vidal and Riesling [8]. The production of this wine type always depends on weather. Bad weather seriously can affect the Icewine grape crop thereby many mass production companies hedge against changes in temperature that impact on supply. Warm winter temperatures can significantly limit the winter grape harvest and subsequently the volume of produced Icewine. For example, approximately $60 \%$ of Ontario grapes set aside for Icewine were diverted to late harvest wines in 2001 due to insufficient harvest hour temperatures. In addition to the lost opportunity costs of selling the harvested juice in the form of cheaper late vintage table wine or grape juice rather than icewine, an additional loss is the increased vulnerability of the vines to winter damage [9]. Later harvesting is usually associated with significant losses due to deterioration of harvest from wind, rot and other factors, and possibly lower sugar content levels in grapes. Due to this bad weather conditions, losses in the Icewine industry were estimated in the range of 10-15 million dollars [10].

Additionally, winter hardiness is influenced by vineyard terroir factors and that vines that are water stressed would not be resistant in comparison with non-water stressed vines [11]. The resistance of low winter temperatures is a genetically controlled characteristic and the full expression of that characteristic can be adversely affected by stresses such as over cropping, drought, and diseases. Furthermore, the duration of the cold weather in regard to the vine acclimation and the rate of temperature change can dramatically affect the sustained cold injury [12]. With new viticulture technology for creation of cold-resistant and disease-resistant hybrid grape varieties, the possibility of growing of vines with improved properties has expanded into cold areas.

Climate change-related increases of the temperature, $\mathrm{pH}$ and potassium levels, especially in conjunction with higher sugar concentrations, have a direct influence on wine 
chemistry, as well. It is often believed that relatively low crop load and optimal plant nutrient status are necessary to maximize cold hardiness of grapevines [13]. Also black grape varieties need more sunlight and heat than white grape varieties, to ensure the physiological ripeness of the tannins in their skins. It follows, therefore, that the bigger part of white grape varieties grow in cold regions; for example, Germany, Alsace, Loire Valley [14].

Should be mentioned that grapevine genetics play an important role in the level of cold hardiness of the cultivar. The different vine cultivars have different abilities to withstand cold temperatures and that abilities are determined by evolutionary factors such as its area of origin. The lineage of a particular cultivar, especially a hybrid, can give clues as to its potential cold resistance. Many vine species have been used for hybridization. Most of the cold resistant genes come through American grapevine species such as Vitis labrusca, Vitis aestivalis, and Vitis riparia [15]. In addition to its genotype, the cold resistance of a specific cultivar is determined by environmental conditions, such as seasonal temperatures and their variation, and by vineyard management practices. It is important to remember that exposure to lower temperatures plays a major role in the ability of the vine to acquire its maximum cold resistance. The colder region, provides an opportunity for maximum potential of cold resistance [16].

Other American species (Vitis rotundifolia, for example) are not cold resistant at all. Vitis vinifera is the most common vine cultivar and originated of the Mediterranean areas of Europe. Its ability to withstand cold winter weather is not good. Also, it is highly susceptible to winter and spring temperatures. Therefore, knowledge of the genetic background of a cultivar is a key component to choosing genotypes that are adapted to a particular climate [17].

Vitis vinifera cultivars are more susceptible to cold injury and there is also much variability between them. For example, varieties such as Riesling and Chardonnay are much more cold tolerant than others such as Merlot, Syrah and Semillon. Hybrid varieties are generally more cold tolerant than Vitis Vinifera. Vidal blanc is more cold sensitive than most of the University of Minnesota hybrids such as Marquette that can withstand $-30^{\circ} \mathrm{C}$.

Grapevines have varying levels of crop depending on variety, location, training system and end use of the grapes. Ontario is no exception and in some vineyard blocks, crop levels can be considerably higher than other blocks when used for Icewine production or target (plateau) priced for lower tier wines. Higher crop levels have been associated with lower cold tolerance in previous literature for some hybrid varieties. Furthermore, some Vidal Icewine blocks have had a tendency to show reduced bud survival following some years of Icewine production especially where they have been machine harvested or the block has been used in consecutive years for Icewine production [18]. In general, Chardonnay, Pinot noir and Merlot reduce maximum hardiness due to cropping level and/or timing of harvest. Heavier crop levels and later harvests reduced maximum hardiness especially in cooler, wetter and delayed seasons. For Cabernet franc, Sauvignon blanc and Riesling, crop level and/or harvest date did not generally impact the vine's ability to reach maximum hardiness levels. Over-cropping can reduce maximum hardiness but in poor growing seasons even a balanced vine may have slightly reduced hardiness. Pinot noir vines with more clusters/shoot reduce cold tolerance regardless of harvest date. For other varieties larger crop levels generally reduce cold hardiness throughout all of dormancy in some years. Riesling is more of an exception and do not respond strongly to crop levels but later harvests reduce cold hardiness. Therefore, Riesling vines used for Icewine production may be slightly compromised in some years. 


\section{Used cultivars for Icewine technology}

Resistance to a wide range of diseases is needed, but the production of wine is almost exclusively based on Vitis vinifera cultivars and even new hybrids within Vitis vinifera are poorly accepted owing to the industry's reliance on traditional and easily marketed classic wine grape cultivars[19]. Initially, Icewine was produced only from white grapes, but recently winemakers start to leave vines of the red varieties during winter for expanding of their range. The most utilized kinds of grapes from white varieties are represented in Figure 1. Figure 1 highlights used dark grape varieties.

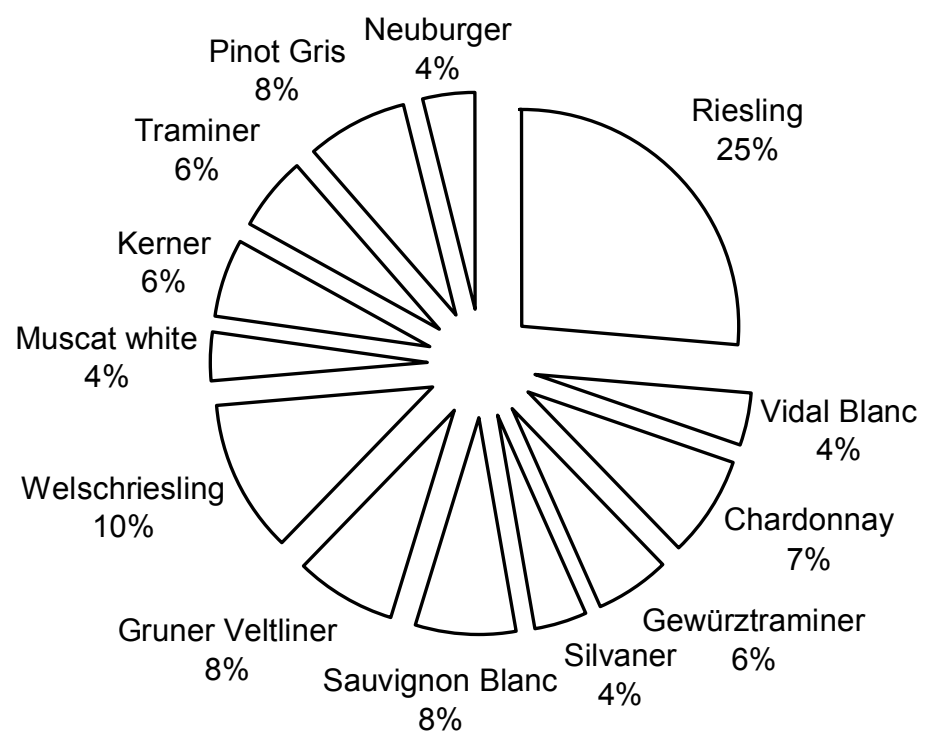

Figure 1. White grapes for icewine making by countries, $\%$

Based on examined data the leaders are Riesling and Welschriesling. Evidenced for that fact is that the $26 \%$ and $11 \%$ relatively of total cultivars are appreciated by producingcountries due to their winter resistance and perhaps the possibility of growing on all grounds in deferent lands.

Welschriesling is a widely planted and well-known variety of Central and Eastern Europe. Welschriesling has many synonyms, including Welsch Rizling (Bulgaria), Laski Rizling (the former Yugoslavia), Olasz Rizling (Hungary), Grasevina (Croatia), and Riesling Italico (Italy). All central located European countries grow this white variety in order to produce exclusive type of wines.

Originated from the Bordeaux region of France Sauvignon Blanc is popular not only in Canada, also in Croatia, Slovenia and Russia for Icewine production. Austrian Icewineis often made from variety Gruner Veltliner that is estimated as terroir autochthonous grape of Österreich. The scientists suggest that it probably derives from a crossing with Traminer [20]. Dry and mild long autumn contribute to the optimum ripeness, juiciness and sugar content for Gruner Veltliner and Silvaner, a white grapes of uncertain origin that is planted in Alsace and more widely in Germany. 
Chardonnay and Sauvignon Blanc are used by winemakers from the Czech Republic, Germany and Slovakia. Additionally, the Royal DeMaria 2000 Chardonnay Icewine is recognized as the most expensive Icewine in the world, retailing at $\$ 250,000$ a bottle [21].

Neuburger is chosen by companies landed on Austria and the Czech Republic. Moldavian, Croatian and Slovenian estates deliver Icewine crops through harvests of Traminer. The Russian Federation mostly sells Riesling and Muscat Ottonel dessert wines that are included to special category.

The most used cultivar is Vidal Blanc in Canada, grape hybrid possessing the appreciated characteristics for high quality wines. Originated from France the sort is widespread across provinces provided annually crop to wineries. Vidal has been widely planted in Eastern and Midwestern states due to its many positive attributes: moderate cold resistance (more than Vitis vinifera varieties), spring frost avoidance (due to late bud break), bunch rot resistance and especially its versatile and desirable wine style and quality [22]. It requires places with long growing seasons and moderate winter temperatures. Bud break is late, which reduces the risk of spring freeze injury. It is characterized by small berries on very large, loose, tapering bunches of grapes. Bunches of grapes thinning is sometimes required to prevent overcropping [12]. Also Chinese wineries adopting the experience of Canadian growers plant basically Vidal near own Huanglong Lake which promotes a cold and not too dry climate [23]. It is important to know that aged icewine from wine varieties Vidal of the Canadian Company "Iniskillin" is defined as the best sweet wine of 2002. Vidal Blanc Icewine of 2013 made by Debonne Vineyards was just named best dessert wine at the 2015 San Francisco Chronicle Wine Competition, one of the largest contests in the United States.

The biggest amount of icewine from North America is produced using FrenchAmerican hybrid, and European countries prefer Riesling. The first icewine in the world was a Riesling, made in British Columbia by Walter Hainle in 1973. Incidentally, Riesling is technical kind of grapes, identified on the banks of the River Rhine. The morphological features and biological properties of Riesling are related to ecological-geographic group to Western European varieties. Riesling is considered to be one of the world's greatest white grape varieties and some of the best white wines were obtained from it. It is a native variety of Germany, where it is believed to have been cultivated for at least 500 years and possibly as long as 2000 years, after all, over 22,000 hectares in German vineyards are planted with Riesling which is about 60 percent of all the Riesling in the world [24]. In addition, numerous comparative trials resulted in more than 80 Riesling clones registered in Germany developed by the breeding department of the Forschungsanstalt Geisenheim [25]. The Riesling grape's ability to retain its acidity while achieving high sugar levels is what creates wines with considerable aging potential [26]. Conclusively, as a result, Riesling can be identified as icewine king due to its good winter resistance and the most expanding across wine regions in the world. This variety is selected by 14 producing countries. On the basis of current researches most of states landed on Europe utilize especially above mentioned white variety. Such countries as Germany, the Czech Republic, Slovenia and Luxembourg basically create Riesling icewines. 


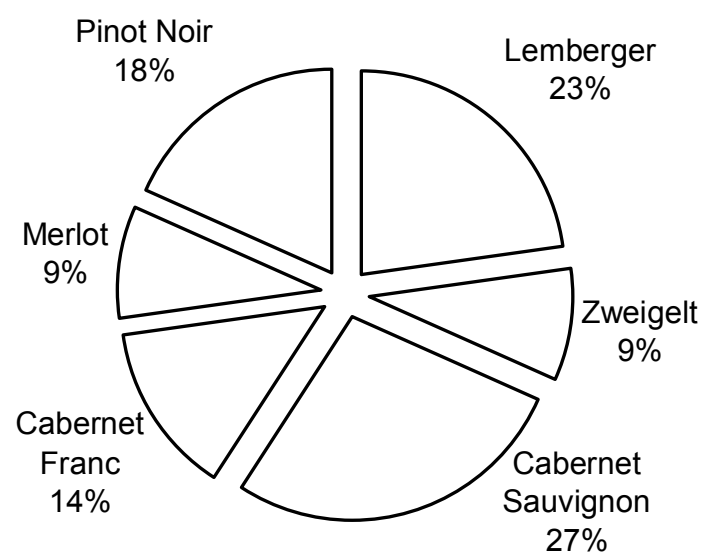

Figure 2. Dark grapes for icewine making by countries, $\%$

Cabernet Sauvignon due to its relatively late maturing is viable grape cultivar for the places with low temperatures. Also this variety has high resistance to mildew and botrytis disease. Better than many other European sorts in the group is opposed to phylloxera and slightly is damaged by grape moth. The point to be emphasized is that many investigates are devoted to evaluate dormant bud cold hardiness of grapes among them scientists and winegrowers often explore parameters of Cabernet Sauvignon [27], [28], [29]. It is variety which was frozen in Brazil [30].

The second position of used red varieties belongs to Lemberger, having many synonyms: Frankova in the Czech Republic, Frankovka modrá in Slovakia, Blauer Limberger or Blue Limberger in USA, but Austrians call it Blaufränkisch like Vitis vinifera name. The most popular dark grape variety in Canada and United States of America is Cabernet Franc. According to data from Annual Report [31] in Canada there was a substantial 68\% increase in the production of Cabernet Franc Icewine in 2015.

However, Canada is considered for the biggest Icewine producer by volumes. Wineries from Germany plant the significant number of diverse grapes for atypical technology. All aforementioned grapes varieties are included in Icewine production, except for Vidal and Traminer. Despite varieties shown in Figures 1 and 2, such grapes as Muskat Trollinger, Trollinger, Gold Muscat, Huxelrebe, Ehrenfelser, Cabernet Mitos are used by Germans to obtain of elite quality drinks. The last three grapes varieties were investigated by the Geisenheim Grape Breeding Institute. Exactly from Huxelrebe was produced first batch of Polish icewines at Jagiellonian University [32]. Anselmann Winery has icewines of the grape varieties Silvaner, Chardonnay, Dornfelder, Cabernet Sauvignon, Pinot Noir and St. Laurent.

The comprehensive range of current grapes varieties by countries is presented in Figure 3. From the analysis can be concluded that Germany, Austria and the Czech Republic have a diverse market of Icewine that is made from different grape varieties. 


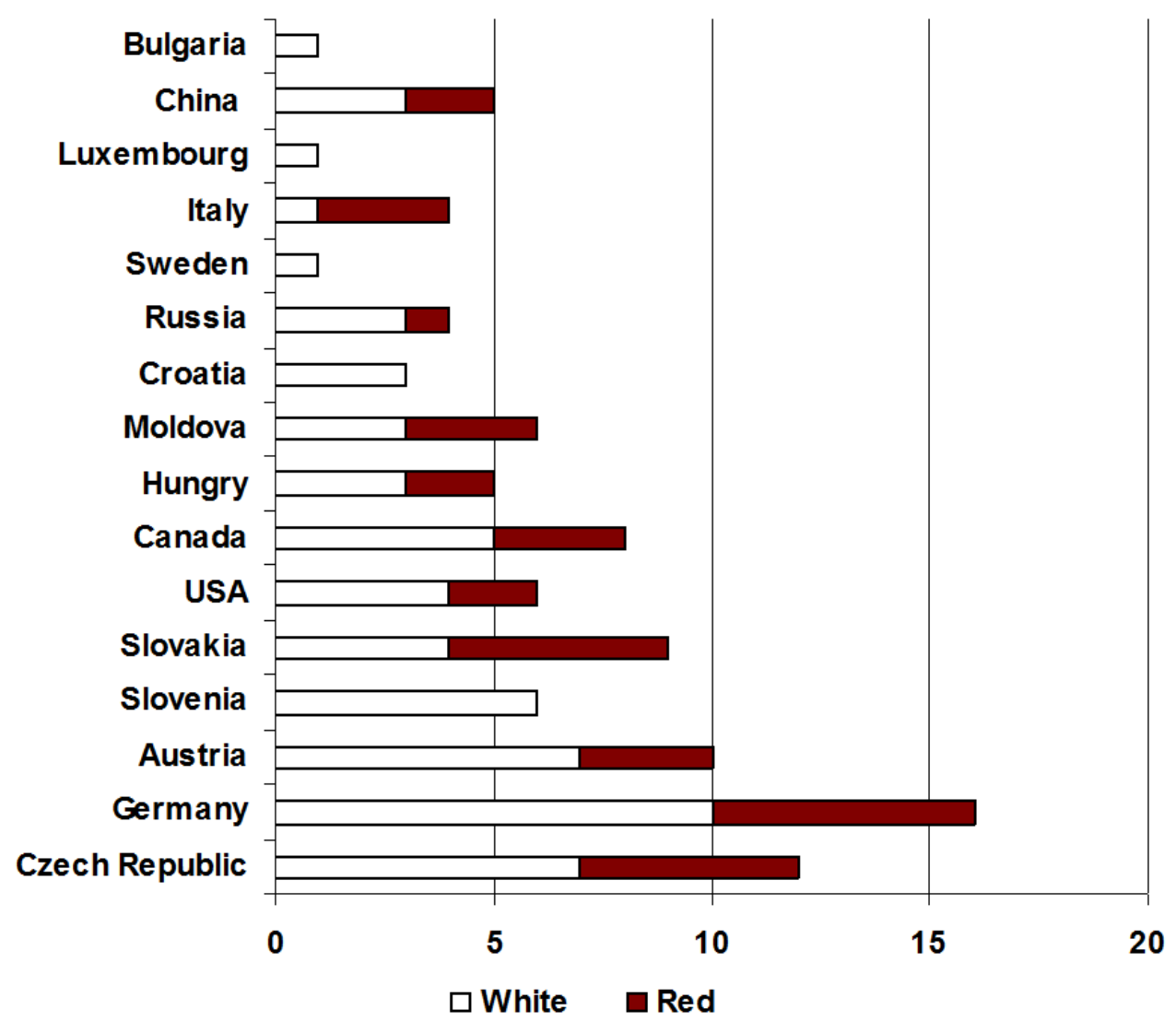

Figure 3. Range of grape varieties that used for production of icewine in different countries

Such countries as Luxembourg, Sweden, Slovenia and Croatia leave exclusively white berries on the vines to become shriveled. Icewine technology in Luxembourg is described in the law represented in official site of the Institute Viti-Vinicole Grand Duché de Luxembourg. According to it premium wines can be made from the varieties Pinot Blanc, Pinot Gris and Riesling[33]. The North Countries represented in this study have preference to Vidal. In the smallest European countries wines are produced from Riesling. It was found that Slovakia is only country that produces icewines by using more dark-skinned varieties than light. The majority of wineries prefer white frozen grapes. Germany, Austria, Canada and USA use the similar grapes including Kerner, Gewürztraminer, Cabernet Sauvignon and Riesling.

Figure 4 appoints the classification of made icewines by type of grape where the varietal exceeds the blended by $56 \%$. It is possible to obtain sweet stable wine easily using one type of grapes than several. But mix icewines are yielded in Moldova, Italy, Austria, Russia and USA. In the last country concentrated grape must was blended with red raspberry wine in Arrowhead Wine Cellars, Pennsylvania. Pioneers of icewine usually use one variety. 


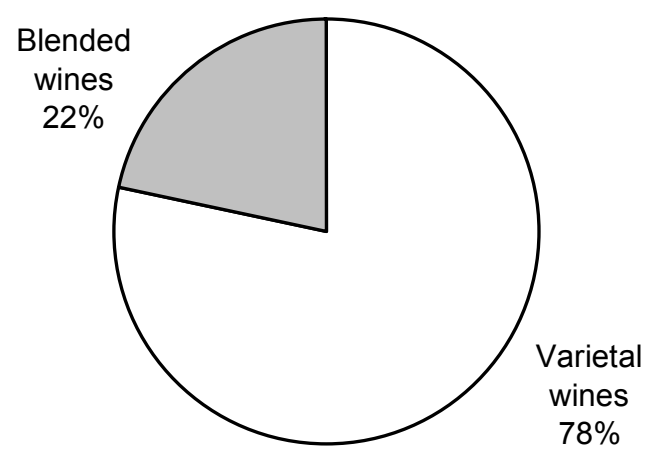

Figure 4. Percentage of icewines produced by type of wine

Nowadays breeding of the new cultivars is developed by growers with helping scientists. Hence, special programs for planting of cold resistant grape varieties were conducted based on further crosses using French hybrids, native American species, and Vitis vinifera varieties at Cornell University and University of Minnesota. Currently led by grape breeders and Professor Bruce Reisch, the Cornell Breeding Program at the New York Agricultural Experiment Station in Geneva has used interspecific hybridization to select wine grapes with cold resistance, high yield, disease resistance and high wine quality. 'Cayuga White,' 'Melody,' 'Chardonel,' 'Marquis,' and 'Traminette' were released based on the investigations of above mentioned university. «GR7» (Geneva Red 7) - is a highly healthy, productive and winter resistant grape cultivar, with moderate resistance to diseases. His red wines have a classical hybrid aroma, better tannin structure than Baco Noir and De Chaunac. It has a place in the traditional red hybrid blended wines, and it is already in limited commercial production. The University of Minnesota initiated its breeding program for wine grapes in the mid-1980 and, in 2000, completed a state-of-the-art enology lab and research winery. In the period from 1996 through 2006, the University of Minnesota breeding program developed and released four cold resistant, productive, moderate- to highly-disease resistant wine grape varieties-Frontenac, Frontenac Gris, La Crescent and Marquette [34].

Despite the high yields of icewines made from Vitis vinifera, hybrids and autochthonous grapes are often used possessing the highest resistance to impact of low temperatures. While there are many individual weather and climate factors that can affect grape growth and wine quality (e.g., solar radiation, heat accumulation, extreme temperatures, precipitation, wind, and extreme weather events such as hail). Growing season length and temperatures are critical aspects because of their major influence on the ability to grapes ripening with achievement of optimum levels of sugar, acids, and aromatic components in order to maximize of the wine quality [35]. Also training system can influence on bud survival in cool climates reviewed by [36] according to it the right choice of grapevine growing is useful to obtain successful crop. Large diameter canes are less winter resistant. Therefore, diverting or reducing vigour through management practices or using a divided canopy system may improve sunlight exposure of shoots and increase the resistance [18].

Having regard to investigates edited by Reisch Bruce I., Pool, \& Peterson (1993) [37], the most susceptibility of grape varieties to low-temperature injury are Elvira, Saint Croix 
and Ventura, American types derived from Vitis labrusca. But in common used varieties to obtain icewines is included Vitis vinifera, that were identified as the most cold sensitive [38]. Consequently, many producing countries step by step have switched to indigenous grapes.

Current study shows the first frozen grape varieties in different countries, among them are Italy, Hungary and Bulgaria produced premier icewines from indigenous grapes. It was noticed that Riesling had been commonly used for icewines by first producers due to its wide spread and winter hardiness. The Riesling grape has ability to retain its acidity while achieving high sugar levels. This creates wines with considerable aging potential. The main significance of aforementioned cultivar is its high acidity that harmonizes the final sweetness of the resulted icewine. The first icewine in Romania was obtained from Traminer. Slovakia obtained first icewines using Gruner Veltliner. China used Vidal. Chateau Pajzos became the first Hungarian winery for production of Tokaj Icewine that was yielded not from Riesling and from indigenous variety called Furmint. The Perico Winery, located in Brazil, firstly produced wines from Cabernet Sauvignon when temperature dropped to $-7.5^{\circ} \mathrm{C}$ in Santa Catarina wine region [30].

Italians produce icewines using only domestic varieties - Avanà, Becuet, Chatus in mix. The Prié blanc is the only one native white-berried variety from Aosta Valley. It is employed by company Cave Mont Blanc Morgex. The Winery at Spring Hill located in Ohio, USA makes icewines from Noiret that is a product of the Plant Breeding Program at Cornell University. This variety results in a fine, full bodied red wine with characteristic of peppery notes. Therefore, Kiona Estate crafted icewines from variety Chenin Blanc and Cave B Estate Winery makes icewine from Semillon grapes in Washington. Furmint is widely used only for making sweet Tokaj, but Hungaria showed that white grape varieties also is intended for icewine production. Consumers can find icewines from Bulgaria that grows Mavrud to production of rare beverages. «Johanneshof-Reinisch», Austrian winery presented "Eiswein" utilizing Zirfandler, autochthonous cultivar that can find in the Thermenregion. Alibernet (Odesskij Chernyj) was bred in 1950 in the Ukrainian Scientific Research Institute of Wine and Vines in Odesa, but then announced grape was developed in former Czechoslovakia. Due to its late-ripening, it requires the best positions, harvests are regular and high. Such grape benefits were attracted by winegrowers in the Czech Republic to freezing. Winemakers from Slovakia plant own native grapes. Among them Andre and Devin are suitable for icewine production.

\section{Harvest conditions}

Weather conditions during the growing season and during the dormant period can have an impact on vine health and cold resistance to low winter temperatures. There are many factors which must be considered in selecting of icewine grape varieties. The most important factors are climate and topography of a prospective site. Other factors include slope-aspect and soil conditions [39]. In order to obtain certain amount of grapes and avoid the losses in such conditions winemakers should monitor temperature levels before harvest.

Monitoring of the temperatures in the vineyard is very important. Each site has specific characteristics - topography, soils, cultivars, cropping history and many others that influence vine resistance. The local or vineyard climate can vary within the vineyard from east to west and from north to south depending on the size and natural slope of vineyard. For this reason, multiple stations have been located throughout the grape growing regions of Ontario and have demonstrated that on a single night the lowest cold temperatures can differ by up to $5^{\circ} \mathrm{C}$ or more. 
In order to obtain suitable crop for Icewine growers and winemakers should be sure in the area weather conditions whereby the wine volume always depends on winter season. Icewine is produced in all wine production regions of Canada; however, the main part of icewine production is in Ontario, principally the Niagara Peninsula, where the summers are warm and the winters are cold. This climate is suitable for optimal grow [40]. Although Ontario is not unique in producing of Icewines. It is the major wine region that has the climate capable to allow the icewine production almost every vintage.

The Niagara Peninsula region has cold climate. The region is situated near $\mathrm{N}^{\circ} 3^{\circ}$ latitude, with relatively high variation in day-night temperatures and substantial sunshine during the growing season. Three of the five Great Lakes of central North America - Lakes Huron, Erie and Ontario formed Ontario's wine regions. During winter the lakes do not freeze, their warmer water helping in the protection of their shoreline vineyards against vine-destroying deep freezes. This combination provides the development of more complex and intense grape flavours during ripening than warmer climates.

Lake Erie is a multi-state American Viticultural Area (AVA) in the Great Lakes region of the northern United States. As might be inferred from the title, most of the AVA's vineyards are located along the shores of this most southerly of the Great Lakes, stretching through New York and Pennsylvania before reaching the vineyards of northern Ohio. Most of the viticulture lands lie along the edges of the lake or near water, where the temperatures are moderated by the insulating capacities of the water. By the same token such distribution is suitable for cultivation of grapes widespread for Icewine making. This arrangement provides a unique micro climate where the large mass of lake water holds heat from the summer, moderates local temperatures and provides warm breezes through autumn to delay typical first frost into November and conversely the lake moderates winter low temperatures, but keeps the area cooler into the spring, delaying first budding until past the typical last frost date[41]. Thus, the biggest share of Icewine production and sales belongs to upstate the Finger Lakes located in the middle of New York State. The most of wineries centres on main lakes named Canandaigua, Keuka, Seneca and Cayuga. The climate of these areas provide temperate conditions suitable for viticulture. Furthermore, American native grapes varieties are established with the highest hardiness ratings compare to grape varieties obtained from Vitis vinifera [28]. Proof of that is estimation of the economic losses during winter season. They were conducted by The OSU Grape Team in Ohio State according to its average estimated crop loss, total estimated grape and wine value loss and average loss per acre of Vinifera Grape Varieties exceed than harms of American Grape and Hybrid Grape Varieties [42].

There is different type of climatic conditions which significantly influence grape growing of each country across Europe. The warmest wine-growing region is Moravia in the Czech Republic. It is the most favourable in temperatures in the comparison with the Mikulov and Velké Pavlovice regions for example. Cooler Bohemia region lays in the rain shadow of the Krušné Hory and České Středohoří Mountain ranges. The climate is continental, with the influence of cold invasions and moist air from the Atlantic Ocean or from Siberia. Summer is with intense temperatures. That fact significantly accelerates the grapes ripening [43]. The biggest company producing icewine in the Czech Republic «Znovín» is situated in The Znojmo Sub-region where cold climate contributes to planting Müller Thurgau, Rhine Riesling, Grüner Veltliner (Veltlinské zelené). Although, icewine producers are situated too in all sub regions of the country where the climates are not considered as cold. Croatian winery «Bodren» located in winegrowing region Pregrada, Hrvatsko Zagorje is situated between Alps and Adriatic Sea on the southern foothills of the mount. The climate is continental-type. The microclimatic potential guarantees the 
accumulation of high acids levels in grapes. This has been used as an advantage for production of dessert wines in which the acidity is well balanced against sweetness and reduces the sensation of weight [44]. The continental climate, which means warm summers and cold winters, is defining for wine regions of Germany and Austria. Yet even Germany and Austria underwent climate variations that caused the regular harvest and uncertain supply of icewine from year to year [45].

Besides countries which are commonly considered as areas with cold climates there are states providing icewine making due to its low winter temperatures. The moderate continental Moldovan climate boasts plenty of sunshine and warmth, and is characterized by a long warm period - 260-290 days, and a relatively short cold period that lasts only 75-105 days [46]. That make possible to growing of grape varieties for rare wine style.

The management to protecting grapes against winter damages plays the significant role in controlling of the harvest volumes. One of the methods to prevent potential decrease of grapes yields is netting of vines blocks [47]. Also noise makers and scaring devices ensure the saving vineyards from animals and birds attacks. There is also always the risk for grapes decay before the temperatures are cold enough for an Icewine harvest. Due to study created by [48] estates can indicate spatial and temporal patterns for bird damages on the wine grapes at the level of single vineyards. The potential employing of weather derivatives against temperature related risks is capable to save the grape harvest. This technology is widely used in various agricultural sectors. Consequently, in order to obtain favourable crop for Icewine processing the winemakers should focus on determination of the time for grapes harvest during low temperatures and to select resistant grape varieties.

\section{Impact of grapes on sugar and alcohol content in Icewine}

Icewine is a wine for which the harvest temperature is the most important to achieve the quality finished beverages. As a result, colder temperatures are required to freeze the berry and achieve the desired soluble solids concentration in the must later in the season and, thus, reducing yields [49]. It was noticed, that the date and time of harvest basically impact on composition of frozen grapes. The time period of harvest determines the main biochemical and chemical reactions in icewine. The most important among them are sugar levels and volatiles concentration. The ideal temperature is between -10 and $-13{ }^{\circ} \mathrm{C}$ before picking. This provides the optimum sugar levels and good flavor in the grapes. The dependence of sugar content from temperature is highlight in Table 1. The data about sugar levels in grape must from Canada is presented in Figure 5.

Table 1

Dependence of sugar content from temperature

\begin{tabular}{|c|c|}
\hline Temperature, ${ }^{\circ} \mathbf{C}$ & Sugar content, $\mathbf{~}$ \\
\hline-6 & 29 \\
\hline-7 & 33 \\
\hline-8 & 36 \\
\hline-9 & 39 \\
\hline-10 & 43 \\
\hline-11 & 46 \\
\hline-12 & 49 \\
\hline-13 & 52 \\
\hline-14 & 56 \\
\hline
\end{tabular}


Higher sugar concentration is observed during autumn season. Higher sugar levels occur in freezing grapes. Should be noted, that the optimal days for harvest were fixed in the middle of December, but wineries determine the final time for harvest based on current weather conditions when air temperature is appreciated. The latest dates of gather were defined as not favorable for icewine making due to low-quality grapes that had been rotten. But according to researches of Canadian winemakers and scientists the highest concentrations of aroma compounds were estimated from grapes harvested with increasing hang time. Unfortunately, the complete composition of the Icewines made from only Riesling, Vidal and Cabernet Franc from Canada are described in scientific literature.

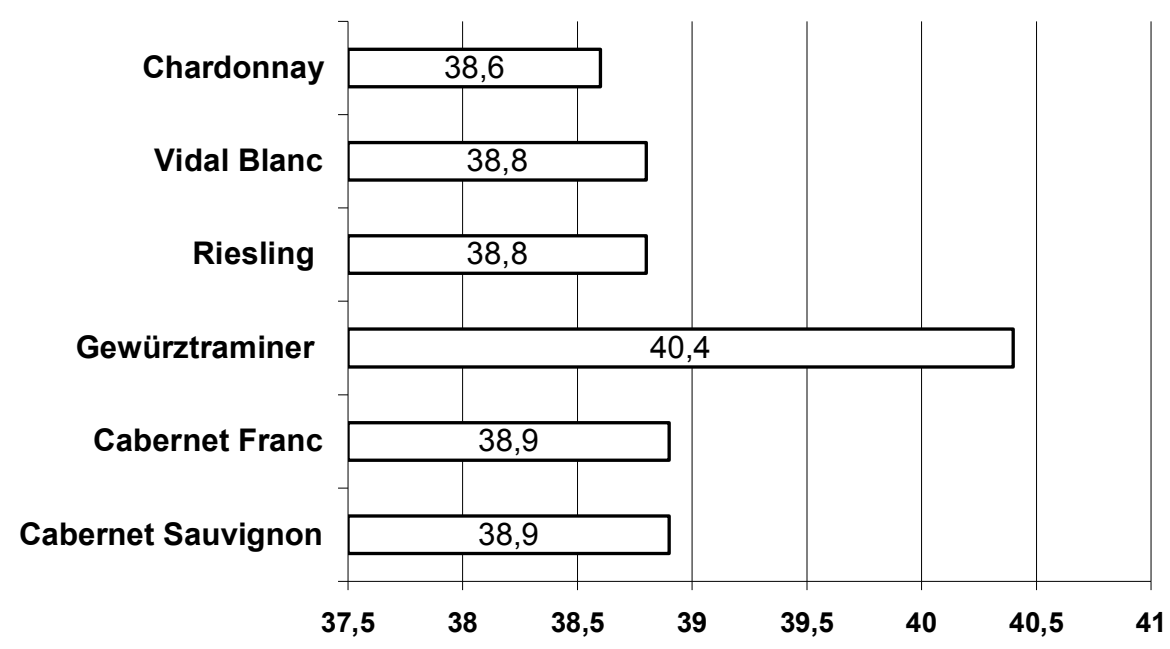

Figure 5. Sugar of must from frozen grapes in Canada, ${ }^{\circ}$ Brix

The most concentrated grapes make challenges for providing of Icewine production: slow fermentation rates, difficulties in reaching $10-11 \%(\mathrm{v} / \mathrm{v})$ ethanol in the wine before the yeast stop fermenting and overproduction of glycerol that influence higher concentration of volatiles predominantly acetic acid. Increasing Icewine juice concentration from 40 to $46^{\circ}$ Brix decreases yeast growth, sugar consumption rate, the total amount of sugar consumed and the total amount of produced ethanol. Increasing The sugars in the grape must for Icewine production lead to raises of the proportion of yeast sugar metabolism diverted away from growth and towards glycerol and acetic acid production. This leads to increased osmotic stress. The acetic acid presented in Icewine at certain levels is not an indicator of microbial spoilage, but rather is a natural by-product of wine yeast fermentation under hyperosmotic stress that may be of benefit in the overall sweetness to sourness balance of the wine. In higher levels it exerts a negative influence overall wine quality [50].

It should also be emphasized that alcohol content differs among countries. Typically, premium wine contains $9-12 \%$ alcohol while icewine from Germany and most of European countries have $7-10 \%$ ethanol. This fact can be explained by the time of the harvest contributed largely on concentrating of grapes. In some parts of Europe, the vintage is done at a temperatures of minus $7{ }^{\circ} \mathrm{C}$. Winery Klet Zorenč - Hohnjec from Slovenia offers premium wines contained more than $14 \%$ alcohol that represents the highly alcoholic 
icewine among another types from other countries. Also enterprise Moravčíkova vína from the Czech Republic produces icewine contain 14\% alcohol. An ethanol concentration in icewines directly correlates with sugar levels and the use of yeast strains for fermentation.

The choice of yeast strain can contribute to the consistent production of high quality wines with unique styles and characteristics. Therefore, the most of articles, investigations and research works are dedicated to ascertaining of convenient yeast strains for providing fermentation [51], [43], [53], [54], [55]. The only weather condition required for a successful harvest is the amount of time between the desired temperature. Other climatic factors such as humidity or wind speed do not affect the quality of the harvested grapes [9].

Similar in character to Icewines, but with less pronounced sweetness and intensity are Late Harvest wines. They are made from grapes harvested after the regular fall harvest but before Icewine harvest. They range from Special Select Late Harvest (sweet and almost like Icewine) to Select Late Harvest to Late Harvest (usually just sweeter than an off-dry or medium table wine) [56].

\section{Prices of Icewines made from diverse grapes}

Quality signals are important price determinants. An objective quality measure is very difficult to define. Many of the sensory indicators that determine expert quality ratings are subjective. Additional indicators, such as labeling, bottle design, or the reputation of producers and regions may also advance or hinder the sale of a particular wine [57].

Bodren Icewine 2009 (Vrhunsko), Regional Decanter Award Winner 2011 from Croatia costs 63 euro per $250 \mathrm{ml}$ bottle while price of Cuvee Ledeno Vino (Icewine) 2008 of this estate is 38 euro. Also Canadian company Inniskillin is considered as brand of Icewine selling their bottles of $0,375 \mathrm{ml}$ priced more than 70 dollars. However, Icewine from Riesling is more expensive than wine made from Vidal of this winery. But evidenced fact that Oak aged Vidal Icewine is the most known premium beverage thereby has the highest price than another wines. Also with the same charges American wines are sold, but the highest values of icewine $s$ were pointed in the New York state exactly in shops of wineries located in the Finger Lakes area.

The prices of German Eiswein are different depending on wine region, popularity of winery and historical roots of exclusive wine establishing. The white icewine s have bigger circle of customers and cost relatively higher while red Icewines are less common inside market. The analyzed data for current study shows that Riesling and Chardonnay Icewines are the most expensive contrary to wines produced from another cultivars. The prices of rare wines from ingenious varieties are quite different among countries. It was noticed that elite wines cost more in that case if adverse weather conditions occur during grape Icewine season.

Due to consolidation position including necessary characteristics suitable for Icewine production mentioned grapes are chosen mostly. Also marketplace of estate in ice category, management of advertisement and tax policy impact the price of premium wine bottle. The major of producers despite of used grapes from diverse countries have the similar price politic the mean score of which is 40 dollars of 0,3751 bottle. The bottles of 0,2001 and $50 \mathrm{ml}$ cost in average 25 and 10 dollars respectively. Additionally there are not true icewine $\mathrm{s}$ in market produced by alternative methods which have lower prices. However, company Znovin located in the Czech Republic sells their wines with price that is similar to icewine bottle made by non-real producers.

To conclude this part should be noted that choice of used grape do not contribute much to certain price per bottle. Small sizes of describing price about icewines prove the truth of different harvest time that make impossible to analyze bigger amount of wines per one 
period. The significant role belongs to harvest time, reputation of winery and risks of producers. The above listed factors largely determine the management of pricing model of Icewines.

The findings reported here can be useful for growers and especially for further investigations related to icewine technology. As icewine making is not studied in whole aspects, the next researchers should be directed to discussion of the data confirmed based on the true choice of varieties for atypical technology in various producing-countries.

\section{Conclusions}

Weather conditions are the most important factor for Icewine production generally, thereby the grape choice plays useful role to achieve harvest for rare beverage. Despite of popular ascertainment of Vitis vinifera Icewine production basically from white cultivars, the hybrids and native varieties are still widely utilized because they tolerate much lower temperatures and break bud later in the winter season. Their resistance or tolerances to many of the common diseases that affect grapes also contribute to popularity between estates making premium wines. Only seven counties had used native grapes for obtainment of first premium wines bottles. White grapes used for production of Icewine are more diverse group. Riesling and Welschriesling are common used and that determine them as the leaders in whole category. The red Icewine production used predominately Cabernet Sauvignon and Lemberger. According to this review each country selects the most suitable varieties possessing the necessary grape characteristics for Icewine developing. Varietal choices made by individuals should be made in the context of climate, site quality, management, and the suitability of varietals from an agronomic and marketing perspective.

\section{References}

1. Hope-ross P. (2006), Analysis in Brief From the Vine to the Glass: Canada' s Grape and Wine Industry From the Vine to the Glass, Canada 's Grape and Business and Trade Statistics Field, 11 , pp. $1-11$.

2. Reynolds A. G. (2010), Managing Wine Quality. Volume 2: Oenology and Wine Quality, Andrew G. Reynolds, ed., Woodhead Publishing, Oxford.

3. Nurgel C., Pickering G.J., Inglis D.L. (2004), Sensory and chemical characteristics of Canadian icewine s, Journal of the Science of Food and Agriculture, 84(13), pp. 1675-1684.

4. Ananicz M. (2011), Winter Gift in the Glass, 35th Annual New York Wine Industry Workshop, pp. 27-35.

5. (2015)4. Special wines. 4.7. Icewine - Eiswein (OENO 6/03), pp. 6-7.

6. Hannah L., Roehrdanzb P. R., Ikegamib M., Shepardb A. V., Shaw M. R. et al. (2013), Climate change, wine, and conservation, Proceedings of the National Academy of Sciences, 110(17), pp. $6907-6912$.

7. Bowen A.J. (2010), PhD Thesis, Elucidation of Odour-potent Compounds and Sensory Profiles of Vidal blanc and Riesling Icewines from the Niagara Peninsula: Effect of Harvest Date and Crop Level, Brock University, St. Catharines.

8. Soleas G.J., Pickering G.J. (2007), Influence of variety, wine style, vintage and viticultural area on selected chemical parameters of Canadian Icewine, Journal of Food, Agriculture and Environment, 5(3-4), pp. 97-102.

9. UrveyT., Weersink A.(2006), Pricing Weather Insurance with a Random Strike Price: the Ontario Ince-wine Harvest , the American Agricultural Economics Association Annual MeetingProvidence, Rhode Island( July 24-27, 2005), pp. 696-709.

10. Cyr D., Kusy M. (2007), Identification of Stochastic Processes for an Estimated Icewine 
Temperature Hedging Variable, American Association of Wine Economists Editor, (5), pp. 1-21.

11. Jasinski M., Reynolds A. (2011), The Terroir of Winter Hardiness, Abstracts from Presentations at the ASEV Eastern Section 36th Annual Meeting \& National Viticulture Research Conference, Towson, p. 555A.

12. Bordelon B. (2009), Grape Varieties for Indiana, Purdure Extension, pp. 1-10.

13. Davenport J.R., Keller M., Lynn J.M, (2008), How Cold Can You Go? Frost and Winter Protection for Grape, HortScience, 43(7), pp. 1966-1969.

14. Grainger, K., Tattersall, H. (2007), Wine Production: Vine To Bottle, Blackwell Publishing, Oxford.

15. Fennell A. (2004), Freezing tolerance and injury in grapevines, J. Crop Improv., pp. 201-234.

16. Zabadal T., Dami I., Goiffinet M. (2007), Winter injury to grapevines and methods of protection, Michigan University Extension, pp. 15-18.

17. Stafne E.T., (2004), Factors affecting cold hardiness in grapevines, Department of Horticulture and Landscape Architecture, Oklahoma State University, Stillwater.

18. Willwerth J., Ker K., Inglis D. (2014), Best Management Practices for Reducing Winter Injury in Grapevines, Cool Climate Oenology and Viticulture Insitute, Brock University, St. Catharines.

19. Linda F Bisson, Waterhouse A. et.al. (2002), The present and future of the international wine industry, Nature, 418(68), pp. 969-699.

20. Steurer R. (2009), Rebsorten des Straßertales, Broidl, Berlin.

21. Royal DeMaria, available at: http://www.royaldemaria.com/

22. Dami I. (2014), Winter Survival of Vidal Blanc Vines for Icewine Production, Wines \& Vines, pp. $78-81$.

23. Lu J. (2015), Grape Wine Today in China, Analysis of China wine industry, pp. 1-85.

24. (2011), The magazine of the german wine institute Oechsle, Deutsches Weininstitut, pp. 1-71.

25. Regner F., Wiedeck E., Stadlbauer A., (2000), Differentiation and identification of White Riesling clones by genetic markers, Vitis, 39(3), pp. 103-107.

26. Liu L., Cozzolino D., Cynkar W.U., Dambergs R.G., Janik L. et al. (2008), Preliminary study on the application of visible-near infrared spectroscopy and chemometrics to classify Riesling wines from different countries, Food Chemistry, 106(2), pp. 781-786.

27. Wolf, T., Cook M.K. (1994), Cold hardiness of dormant buds of grape cultivars: Comparison of thermal analysis and field survival, HortScience, 29(12), pp. 1453-1455.

28. Pool R.M., Reisch B.I., Welser M.J. (1990), Use of different thermal analysis to quantify bud cold hardiness of grape selections and clones, Proceedings of the V. International Symposium on Grape Breeding, Geneva, New York, USA, pp. 318-329.

29. Wolf T. (2011), Cover Crop, Rootstock, and Root Restriction Effects on Cabernet Sauvignon Dormant Bud Cold Hardiness, Abstracts from Presentations at the ASEV Eastern Section 36th Annual Meeting \& National Viticulture Research Conference, Towson, Maryland, p. 556A.

30. Langman, J. (2009), Icewine produced in Brazil for the first time. Decanter.

31. (2016), Annual Report 2015 Vitners Quality Alliance, available at: http://www.vqaontario.ca.

32. Bednarczyk J. (2012), Jagiellonian University vineyard will make icewine, Science and Scholarship in Poland, pp. 25-29.

33. (2016), The icewine has been harvested, The ofifcial portal of the Grand Duchy of Luxembourg, available at: http://www.luxembourg.public.lu/en/actualites/2016/01/25-vinglace/index.html

34. Covert C. (2008), Cold Climate Grape Varieties From Eastern U. S. Breeding Programs, Foundation Plant Services, pp. 10-12.

35. Jones G., White M. A, Cooper O.R, Storchmann K. (2005), Climate change and global wine quality, Climatic change, 73(3), pp. 319-343.

36. Reynolds A.G., Vanden Heuvel J.E. (2009), Influence of grapevine training systems on vine growth and fruit composition: A review, American Journal of Enology and Viticulture, 60(3), pp. 251-268.

37. Reisch Bruce I., Pool R., Peterson D. (1993), Wine and Juice Grape Varieties for Cool Climates, A Cornell Cooperative Extension Publication, 2, p.6.

38. Dami I.E., Ennahli S., Zhang Y. (2012), Assessment of winter injury in grape cultivars and pruning strategies following a freezing stress event, American Journal of Enology and Viticulture, 
63(1), pp. 106-111.

39. Perry R., Sabbatini P., Burns J. (2012), Growing Wine Grapes in Michigan, Department of Horticulture, Michigan State University, East Lansing, pp. 353-355.

40. Bowen A.J., Reynolds A.G. (2015), Aroma compounds in Ontario Vidal and Riesling icewines. I. Effects of harvest date. Food Research International, 76, pp. 540-549.

41. (2015), Wine Catalog. Premier Award-Winning Wines Since 1968, available at: www.piwine.com.

42. Dami, I., Lewis D. (2014), 2014 Grape Winter Damage Survey, The Ohio State University, Columbus.

43. (2006), Wines from Moravia and Bohemia - Czech Republic, available at: http://www. wineofczechrepublic.cz.

44. (2011), Notes on Bodren Ice and Sweet Wines from Continental Croatia, available at: www.croatianfinewines.com.

45. Jones G.,Hirasawa J. (2011), Inniskillin and the Globalization of Icewine, Harvard Business School, (Mba 2005), pp. 1-27.

46. Inkpen A., Phillips R. (2006), The Wine Industry, Moldovan Investment and Export Promotion Organisation, 44, pp. 1-17.

47. Inglis D.L. (2011), Extreme Winemaking in the Canadian North. Sweet success and sour pitfalls in Icewine production, Brock University, St. Catharines.

48. Somers C.M., Morris R.D. (2002), Birds and Wine Grapes: Foraging Activity Causes SmallScale Damage Patterns in Single Vineyards, Journal of Applied Ecology, 39(3), pp. 511-523.

49. Bowen A.J., Reynolds A.G. (2012), Odor potency of aroma compounds in Riesling and Vidal blanc table wines and icewines by gas chromatography-olfactometry-mass spectrometry, Journal of Agricultural and Food Chemistry, 60(11), pp. 2874-2883.

50. Pigeau G.M., Bozza E., Kaiser K., Inglis D. (2007), Concentration effect of Riesling Icewine juice on yeast performance and wine acidity, Journal of Applied Microbiology, 103, pp. 16911698.

51. Erasmus D.J. (2004), Impact of yeast strain on the production of acetic acid, glycerol, and the sensory attributes of icewine, American Journal of Enology and Viticulture, 55(4), pp. 371-378.

52. Martin S.J. (2008), PhD Thesis, The Osmoadaptive Response of the Wine Yeast Saccharomyces cerevisiae KI-Vll16 during Icewine Fermentation, Brock University, St. Catharines.

53. Pigeau G.M., Inglis D.L. (2005), Upregulation of ALD3 and GPD1 in Saccharomyces cerevisiae during Icewine fermentation, Journal of Applied Microbiology, 99(1), pp. 112-125.

54. Inglis D. (2008), Make Icewine Easier, at Least for Yeast, Vineyard Winery Managment, pp. $71-$ 75.

55. Synos K., Reynolds A.G., Bowen A.J. (2015), Effect of yeast strain on aroma compounds in Cabernet franc icewines, LWT - Food Science and Technology, 64(1), pp. 227-235.

56. (2016), Vitners Quality Alliance, available at: http://www.vqaontario.ca.

57. Schamel G., Universit L. (2003), International Wine Trade: Analyzing the Value of Reputation and Quality Signals, the 2003 AAEA Annual Meeting, pp. 1-16. 